\title{
樹木の葉層面積と樹幹・樹枝投影面積分布を 考慮した抗力係数に関する研究 ESTIMATION OF DRAG COEFFICIENT OF A REAL TREE CONSIDERING AREA OF LEAVES AND THE VERTICAL STAND STRUCTURE OF TRUNK AND BRANCHES
}

\author{
竹中宏 1 ・田中規夫 2 \\ Hiroshi TAKENAKA, Norio TANAKA \\ 1学生会員 学(工) 埼玉大学大学院 理工学研究科 (†338-8570 埼玉県さいたま市桜区下大久保255) \\ 2 正会員 工博 埼玉大学大学院教授 理工学研究科・ (兼) 環境科学研究センター \\ (テ338-8570＼cjkstart埼玉県さいたま市桜区下大久保255)
}

\begin{abstract}
Drag coefficients of a real tree trunk and a branch and sheltering effects of upper trunk or branch on downstream one were investigated in detail. Willow and Robinia pseudoacacia were selected for the real trees. Drag coefficient starts to decrease from relatively low Reynolds number and is smaller than that of a smooth circular cylinder in whole Reynolds number range investigated. Leaves increases the drag coefficient around 40 to $100 \%$ with increasing the ratio of leaves in comparison to that with only branch cases. Sheltering effects becomes larger with the existence of leaves. The drag coefficient of downstream branch approaches around $95 \%$ of that of a single branch with increasing Reynolds number notwithstanding the existence of leaves. The moment by drag force of a whole tree was calculated for the strong wind event that overtuned trees in the Arakawa river. The calculated value was compared with the experimental threshold values, and was validated within a reasonable limit.
\end{abstract}

Key Word : surface roughness, Reynolds number, turbulent intensity, drag crisis, sheltering effect

\section{1. はじめに}

河道内に繁茂した樹木群は，生物多様性の向上や堤防 および河岸の侵食を防ぐなど，環境・治水面に効果があ ることが知られている，その一方で，樹林群の規模，密 度，河道に占める繁茂面積の割合などによっては，洪水 時の流下能力に影響を及ぼす場合がある。このため，河 道計画において，樹木群による抵抗を高精度に評価する ことは重要である. 従来, 樹木の抗力を評価する際, 樹 幹部分の抗力係数は滑面円柱の抗力係数 $\left(C_{D}=1.2\right)$ が用い られている場合が多い1), 2)が，実際は複雑でありその妥 当性を検証する必要がある，滑面円柱の場合には，レイ ノルズ数 Re (UL/v, $U$ : 接近流速, $L$ : 代表長さ（直 径），v：動粘性係数）が高く物体表面の境界層が層流 境界層から乱流境界層に遷移する領域では，ドラッグク ライシスと呼ばれる抗力係数の急激な減少が見られる ${ }^{3)}$. この現象は, Reが5×10付近で発生し, 円柱表面から一 度はく離したせん断層が下流側で再付着することによっ
て引き起こされる.この結果, 最終的なはく離点が大き く下流側へ移動し, 抗力係数が 0.3 にまで大きく低下す る。しかし，物体表面の粗度が大きいほど，より低い $R e$ でドラッグクライシスが発生するものの, 抗力係数 はさほど低下しなくなる4)。したがって，樹木の主幹抵 抗を正確に評価するためには，様々な形状の樹皮を有す る樹木に対する抗力特性の知見を得る必要がある5).

また，樹冠域では葉の量によって抵抗が異なることや 枝葉の重なりによる遮蔽効果 ${ }^{6}$ が考えられる. 葉層によ る付加抵抗 $\beta$ : 葉による抵抗係数の付加を表す無次元量 （=葉のついた状態での抗力係数／葉を取り去った状態 での抗力係数) は福岡ら ${ }^{7)}$ にり $1.2 \sim 1.3$, Armanini $5^{8)}$ により実物大のヤナギでは1.4などの知見が得られてい るが，様々な樹木に対して十分な知見が得られていると は言えず，これらのより詳細な検討が必要である.

風工学で実樹木の抵抗を評価している事例はあるもの の，洪水の場合は水深によって幹部分が水につかる場合 や樹冠部分までが水につかる場合など条件によって抗力 特性が異なることが考えられる.さらに，樹木が密に生 
育しているような樹木群の場合, 上流側の樹木による遮 蔽効果が樹木群の抵抗特性に影響を与えると考えられる. 樹皮の粗度が樹種によって異なるため後流が異なり, 後 方の樹木への影響も異なることが考えられる.

以上を踏まえ，本研究は，樹木鉛直構造(枝の投影面 積, 葉面積/枝面積の分布)を考慮した抗力計算法に必 要な基本要素の詳細について, 風洞実験による特性の把 握，抗力モーメントにより転倒した風倒木の事例と倒伏 モーメント限界值（実験式）の比較により，算出方法の 精度を現地スケールで検証することを目的とする。なお， 実験は風洞で行うものの高Reでかつ枝や葉の変形が生 じる領域で行うこと, また, マッ八数 $(M a=U / a, U$ : 流体の相対速度， $a$ : 音速）が0.02-0.07で 0.3 以下となり, 空気も非圧縮と考えられること，水流で得られている既 往知見と比較すること，実スケールでの検証も行うこと により，洪水流での適用も可能と考えている.

\section{2. 樹木基本要素の抗力測定と抗力モーメント}

\section{高精度評価の検証のための現地調査}

樹木群による抵抗を高精度に評価するために必要な樹 木の基本的要素として，1)樹皮の粗度による影響を考慮 した主幹の抗力係数 $\left.C_{D-r e f}, 2\right)$ 葉層の付加抵抗 $\beta(=$ 葉と枝 をあわせた抗力係数 /枝の抗力係数)，3)樹木間の遮蔽 係数 $S$ (=流下方向に直列に 2 本配列した後方物体の抗力係 数／単一物体の抗力係数）を抽出し，その特性を明確に するために風洞実験を行った。 また, 風洞実験から得ら れた知見を用い，樹木鉛直構造を考慮して抗力モーメン 卜を算出し, 従来の樹冠面積に対して抗力モーメント係 数を求める方法と比較して, 計算方法の現地スケールで の検証を行った（図-1）.

\section{（1）基本要素をスケールアップした抗力と抗力モーメン トの算出方法}

樹木群中の樹木に作用寸る抗力 $F$, 抗力モーメント $M$ は，樹木の鉛直構造を考慮した田中ら ${ }^{9)}$ の方法に主幹部 分の遮蔽係数 $S_{t}$ と樹冠部分の遮蔽係数 $S_{c}$ を加え, 以下の 式(1)- 式(3)を用いて算出した.

$$
\begin{gathered}
F=S \int_{0}^{h} \frac{1}{2} C_{D}(z) \rho u(z)^{2} d(z) d z \\
=\frac{1}{2} C_{D-r e f} \rho U^{2} D_{B H} S \int_{0}^{h} \frac{d(z)}{D_{B H}} \frac{C_{D}(z)}{C_{D-r e f}} d z \\
=\frac{1}{2} C_{D-r e f} \rho U^{2} D_{B H}\left\{S_{t} \int_{0}^{h_{t}} \alpha(z) \beta(z) d z\right. \\
\left.+S_{c} \int_{h_{t}}^{h} \alpha(z) \beta(z) d z\right\} \\
\alpha=\frac{d_{(z)}}{D_{B H}}, \beta=\frac{C_{D(z)}}{C_{D-r e f}}
\end{gathered}
$$

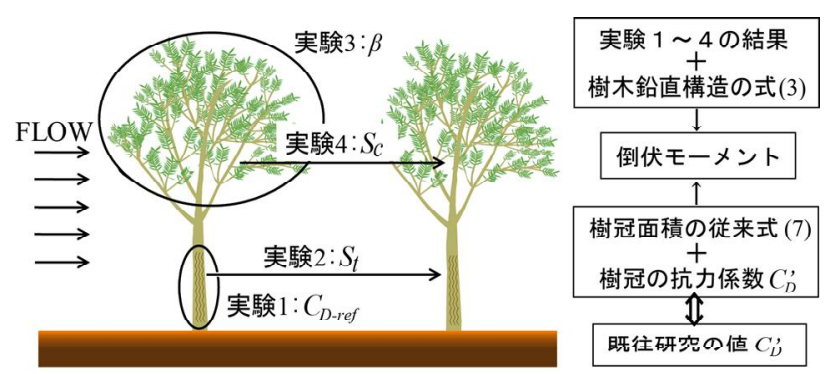

図-1 単一樹木の抗力特性から樹林帯の抗力特性への拡張方法
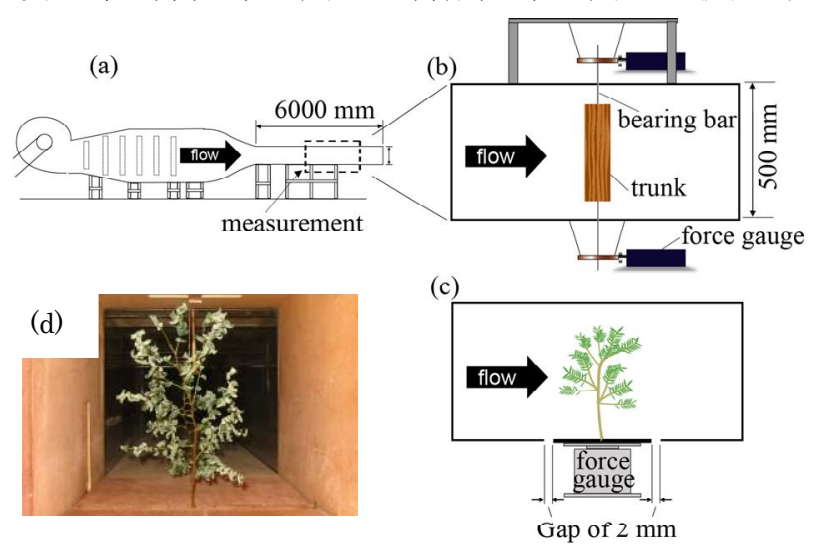

図-2 実験装置, (a) エッフェル型風洞, (b),(c) 抗力測定装置,

(d) 実験に用いたハリエンジュの枝葉の写真

$$
\begin{array}{r}
M=\frac{1}{2} C_{D-r e f} \rho U^{2} D_{B H}\left\{S_{t} \int_{0}^{h_{t}} z \alpha(z) \beta(z) d z\right. \\
\left.+S_{c} \int_{h_{t}}^{h} z \alpha(z) \beta(z) d z\right\}
\end{array}
$$

ここに, $z$ : 河床からの鉛直高さ $(\mathrm{m}), C_{D-r e f}$ : 主幹の抗 力係数, $C_{D}(z), u(z), d(z)$ : それぞれ河床からの高さ $z$ に おける抗力係数, 流速 $(\mathrm{m} / \mathrm{s})$, 主幹と枝の幅の和 $(\mathrm{m}), \rho$ : 流体の密度 $\left(\mathrm{kg} / \mathrm{m}^{3}\right), h$ : 抗力を受けた高さ(今回の場合は 全体なので樹高)(m), $h_{t}: h$ 一(樹冠高さ)(m), $D_{B H}:$ 胸高 直径 $(\mathrm{m}), \alpha(z)$ : 樹形(幹・枝)の相違(高さzにおける幹・ 枝幅の総和を胸高における幅 $d_{B H}$ で基準化した比)を表す 付加係数, $\beta(z)$ : 葉と枝をあわせた抗力係数/枝の抗力 係数, $S$ : 樹木全体の遮蔽係数, $S_{t}$ : 主幹部分の遮蔽係 数, $S_{c}$ : 樹冠部分の遮蔽係数である. また, 流速の鉛直 分布 $u(z)$ を考慮せず，断面平均流速 $U(\mathrm{~m} / \mathrm{s})$ を用いた.

\section{(2) 樹木基本要素の抗力測定実験}

本実験では，図-2に示すエッフェル型風洞（風洞断面 $0.5 \mathrm{~m} \times 0.5 \mathrm{~m}$ ）を使用し，樹木に働く抗力を測定した．樹 木の抗力特性を詳細に把握するため, また，単一樹木の 抗力特性から樹林群の抗力特性へと拡張するために, 1) 幹部分の樹皮影響測定（実験1），2）上流の幹による遮 蔽効果測定（実験2），3）葉による付加抵抗係数の測定 (実験3），4）上流の枝葉の遮蔽効果測定（実験4）を 行った. 樹木は日本の河川に多く生育するヤナギと外来 樹種のハリエンジュを用いた.

a）実験装置および方法（実験1，2） 
図-3に実験に使用した幹モデルの切断面と側面部を示 す. 実験は4種類，すなわち，樹木の幹（表面は粗面 : 以下，ハリエンジュはTrunk-R，ヤナギはTrunk-Wと呼 ぶ），比較実験で使用した塩化ビニル管（表面は滑面 : 以下, Cylinder-Sと呼ぶ) とアスペクト比 $(h / d, h:$ 模 型高さ, $d$ : 模型幅) が異なる円柱 $\left(k_{s} / d(d\right.$ : 胸高直径, $k_{s}$ : 溝の深さ）がTrunk-Rと同様となるような溝を付加 したもので, Cylinder-Rと呼ぶ) で行った.

まず，Cylinder-Sを用いた実験を行ない，既往研究に おけるRe数と抗力係数 $C_{D}$ との関係と比較を行なうこと で，本研究で用いた抗力の測定方法が正しいかどうかの 検証を行なった. 次に，凹凸の樹皮を有するTrunk-R， Trunk-W，Cylinder-Rを用いて滑面円柱と同様の実験を 行ない, $R e$ と抗力係数 $C_{D}$ との関係を把握した.

Trunk-R, Trunk-W，Cylinder-S，Cylinder-Rは風洞の吹 出口から $4 \mathrm{~m}$ の位置に設置した。抗力測定のために，図一 2 に示す位置にプッシュプルタイプの荷重測定器 (AIKOH社製：RX-10)を2箇所設置し，風洞の上下2点で 測定を行い，上部の抗力を $F_{l}$, 下部の抗力を $F_{2}$ とした. 幹モデルに作用する $C_{D}$ は, 以下の式(4)より算出した.

$$
F=F_{1}+F_{2}=\frac{1}{2} C_{D} \rho U^{2} A
$$

ここに, $F$ : 幹モデルに作用する抗力 $(\mathrm{N}), C_{D}$ : 抗力係 数, $\rho$ : 空気の密度 $\left(\mathrm{kg} / \mathrm{m}^{3}\right), U$ : 風洞中央断面での接近 流速 $(\mathrm{m} / \mathrm{s}), \quad A(=d \times L)$ : 主幹の投影面積 $\left(\mathrm{m}^{2}\right)$ であり, $d$ は 主幹の直径 $(\mathrm{m})$, 主幹の長さ $L(\mathrm{~m})$ である.

流速Uは熱線流速計（KANOMAX社製：0249RT5）を用いて計測し，以下の式(5)より算出される入 射風の乱れ強さTIは $0.2 \%$ 以下である.

$$
T I=\frac{\sqrt{\overline{u^{\prime 2}}}}{U}
$$

ここに, $u^{\prime}:$ 接近流速の変動值 $(\mathrm{m} / \mathrm{s})$ である.

\section{b) 遮蔽係数の定義}

遮蔽効果を表す遮蔽係数Sを以下の式で定義する.

$$
S=\frac{C_{D-\text { rear }}}{C_{D}}
$$

ここに, $C_{D-\text { rear }}$ : 後方の模型の抗力係数, $C_{D}$ : 単一模型 の抗力係数である.

同じ種類の幹モデルを流下方向に直列に $2 つ$ 配列し, 下流の幹モデルの抗力係数を式(4)より求め, 遮蔽係数 を式(6)により算定した. 幹モデルの間隔は, Bokain と $\mathrm{Geoola}^{10)}$ を参考に実際の幹間隔を考慮し $l / d(l$ : 幹モデル 間の距離, $d$ : 幹モデルの直径 $)=1.5 \sim 200$ 範囲で行った.

\section{c）実験装置および方法（実験3，4）}

図-1 (d) に実験に使用した樹木の枝葉の一つを示す. 抗力の測定は枝葉を3分力計（SSK社製：LB60-10N）に 取り付け，流下方向への成分を測定した. 枝葉はハリエ

\begin{tabular}{|c|c|c|c|c|}
\hline & $\begin{array}{c}d \\
(\mathrm{~cm})\end{array}$ & $\begin{array}{l}k_{s} / d \\
\times 10^{-3} \\
\end{array}$ & $\begin{array}{c}\text { cross } \\
\text { section }\end{array}$ & side view \\
\hline Trunk-R & 7.8 & 45 & & \\
\hline Trunk-W & 7.7 & 11 & & 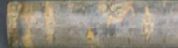 \\
\hline Cylinder-S & 7.6 & - & & \\
\hline Cylinder-R & 2.0 & 45 & 0 & \\
\hline
\end{tabular}
ンジュの枝葉を用い，枝の太さを変え抗力測定を行った. また，葉の影響を把握するため，葉がすべてある状態と

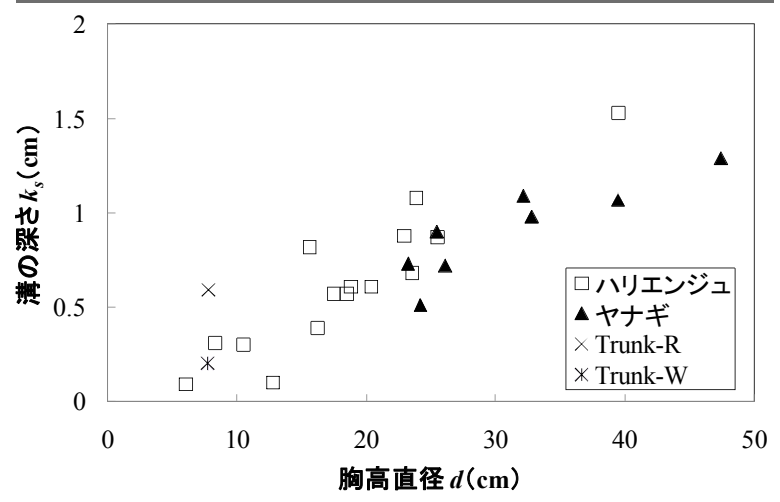

図-3 Trunk-R，Trunk-W，Cylinder-S，Cylinder-Rの断面図と側 面図(樹木の $k_{s} d d\left(d\right.$ : 胸高直径, $k_{s}$ : 溝の深さ)は不規則であ るため最大值を記した)，ハリエンジュ，ヤナギとTrunk-R， Trunk-Wのdとk$k_{s}$ 関係，※Trunk-Wの溝は部分的

葉のない状態で抗力を測定した．樹冠部分では枝葉が密 集しているので, 上流の枝葉によって下流の枝葉が遮蔽 影響を受けていると考えられる. その影響を把握するた め，枝葉を流下方向に直列に2本配列し，下流の枝葉の 抗力を測定した．枝葉の間隔は，実際の樹木の枝葉の間 隔を考慮し, $l / d$ ( $l$ : 枝と枝の距離, $d:$ 枝の直径 $)=60$, 80，100を用いた．単一と同様に遮蔽効果についても葉 の有無で抗力を測定した.

\section{(3) 樹木抵抗の高精度評価の検証のための現地調査}

本研究で測定した抗力係数を樹木スケールにスケール アップした場合に得られる值の確からしさを検証する. 検証材料としては，2009年10月の台風18号による強風 (気象庁HPさいたま市気象台観測，10分ごとの值より， 最大瞬間風速 $19.6 \mathrm{~m} / \mathrm{s}$, 風向 : 南南西)による倒伏樹木 （荒川下流河道内）について，胸高直径，樹高，樹冠高 さ，葉張り，根鉢直径と深さを調査し，投影面積の写真 解析を行った．樹木の倒伏状況は，地盤支持力が弱い地 点に生えた樹木（畑のような箇所にはえた樹木，法面樹 木）や根茎支持力が弱い地点に生えた樹木（干満の影響 をうけ湿地のような環境で育ち根茎が極度に未熟な樹 木 : 生物生態園内樹木) で生じており，平場で地盤条件 の良かったと考えられる樹木は少なかった。しかし，平 場では樹木の倒伏限界モーメント值が引き倒し実験で求 められていた ${ }^{11)}$ た，それとの比較により抗力計算の確 からしさを確認することができる. 
式(1)，(2)，(3)と比較するために，樹冠域に抗力係数 を与える方法は風の外力モーメント ${ }^{11)}$ より算出した.

$$
M^{\prime}=\frac{1}{2} C_{D}{ }^{\prime} \rho U^{2} A H
$$

ここに, $\rho:$ 流体の密度 $\left(\mathrm{kg} / \mathrm{m}^{3}\right), C_{D}{ }^{\prime}$ : 樹冠の抗力係数, $A:$ 樹冠の面積 $(=$ 樹冠高さ $\times$ 葉張り $)\left(\mathrm{m}^{2}\right), \quad U:$ 最大瞬間 風速(さいたま市気象台観測) $(\mathrm{m} / \mathrm{s}), H$ : 抗力中心高さ(枝 下高さ+樹冠高さの三分の一)(m)である.

\section{3. 樹木要素の抗力測定結果}

\section{4つの実験それぞれについて結果を示す.}

\section{(1) 実験1}

図-5は4つの幹モデルのReによる抗力係数の変化を示 したものである。それぞれの樹木は回転させるごとに粗 度の状況が異なることから，90度ずつ回転させ4回測定 を行い, 平均值を求めた. Trunk-R, Trunk-W, CylinderSは一般的によく知られている長円柱の既往研究（1-1. 2）が示す值よりも小さい抗力係数值を示している.こ れはアスペクト比の影響が考えられる. 滑面円柱の抗力 係数はアスペクト比が小さくなるにつれ小さくなること が知られている ${ }^{12)}$. Trunk-R, Trunk-W, Cylinder-Sのア スペクト比は $h / d=4.5$ であり，アスペクト比が大きい円 柱に比へ，円柱上端と下端からの回り込む流れの影響が 大きいので, 抗力係数が小さくなると考えられること， また，既往研究 ${ }^{12}$ と同等の值であることから，抗力測定 方法は妥当であると言える.

一方，どちらの樹木も滑面円柱と比較すると異なった傾 向が見られる. Trunk-Rは $k_{s} / d$ （模型直径 $d$ と粗度高さ $k_{s}$ の比）が既往研究) 比べ大きいことから，樹木表面の境 界層が乱流境界層に移行しきった状態にあると考えられ る. そのためほぼ一定の值を示していると考えられる.

Trunk-W の $C_{D}$ はReが大きくなるとともに徐々に減少し ている. これはTrunk-Wの $k_{s} / d$ が既往研究4) $k_{s} / d=1 \times$ $10^{-3} \sim 9 \times 10^{-3}$ と同じであることから幹表面の境界層が層 流から乱流へと移行している遷移領域であることが考え られる。しかし，樹木の粗度は不規則であるため既往研 究4にあるような大きな変化は見られなかったと考えら れる．ただし，境界層の様子は可視化などを行わないこ とには断定はできない，また，アスペクト比の大きい Cylinder-R（Trunk-Rと同等の粗度）は，同じアスペクト 比の滑面円柱の值に近い值 $C_{D}($ 約 1$)$ をとることがわかっ た. 主幹の抗力係数は，表面粗度の違いにより，滑面円 柱と異なる傾向をReに対して示寸．しかし，樹木モデ ルの場合，滑面円柱 ${ }^{3), 4)}$ や規則的な表面粗度を配置した 円柱 $)^{4}$ のうな急激な $C_{D}$ の低下などは見られない。 また， 同じアスペクト比（約4-5 約18）であれば，ドラッグ クライシスが生じる前の円柱と同等の值をとることが確 認できた. したがって， $C_{D-r e f}$ して1を採用した.

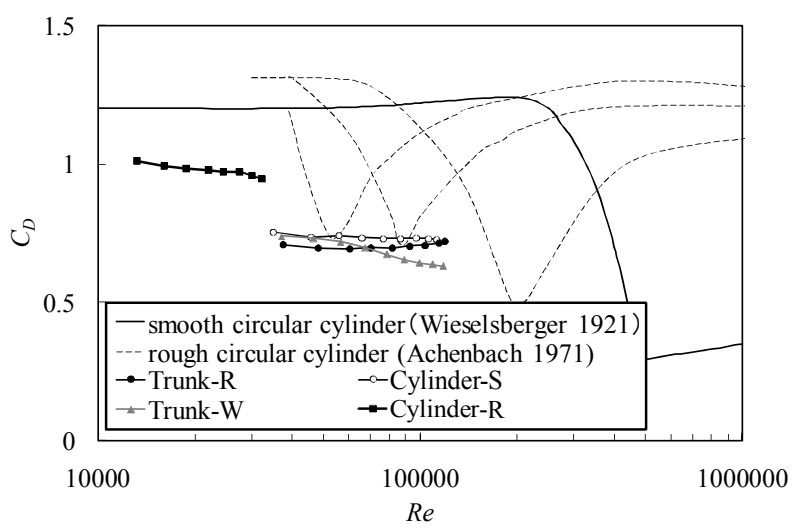

図-5 Trunk-R, Trunk-W, Cylinder-S, Cylinder-RのReによる抗 力係数 $C_{D}$ の変化
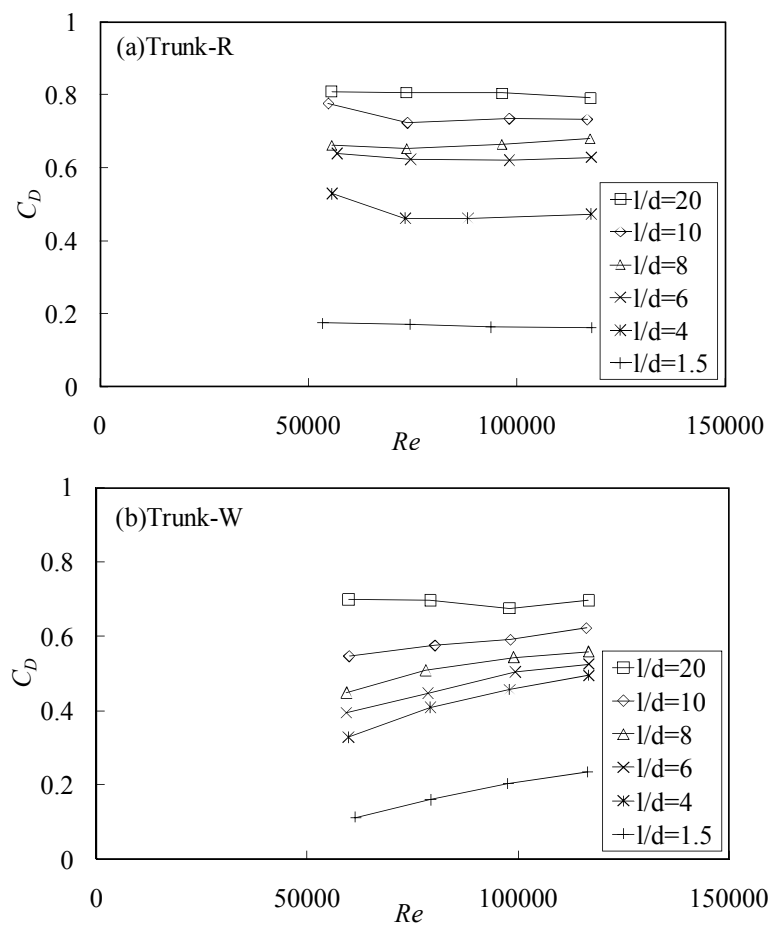

図-6 下流側模型のReによる抗力係数 $C_{D}$ の変化, (a) Trunk-R, (b) Trunk-W ( $l$ : 幹と幹の距離, $d$ : 主幹の直径)

\section{(2) 実験2}

図-6に単円柱の場合と相互干渉の場合のReによる抗 力係数の変化を示す. Trunk-W，Trunk-Rの場合におい ても，lldが小さくなるとともに抗力減少の効果（遮蔽 効果）がみられる。しかし，それぞれ円柱表面の形状の 違いによりReによる抗力係数の変化はまったく違った 傾向を示している. Trunk-W は上流の幹表面の境界層 が遷移領域であり, 後流が層流境界層, 乱流境界層のと きよりも狭くなり, 後方の幹の接近流速が大きくなるこ とが考えられる．そのため，Reの増加とともに抗力係 数が大きくなると考えられる. Trunk-Rの場合は上流の 幹は乱流境界層になり, 後流は一定していると考えられ, 後方の幹の抗力係数もほぼ一定であると考えられる. な お，2種類の異なった樹皮をもつ主幹Trunk-R, Trunk-W を用い考察したが，樹木直径が大きくなると八リエン 

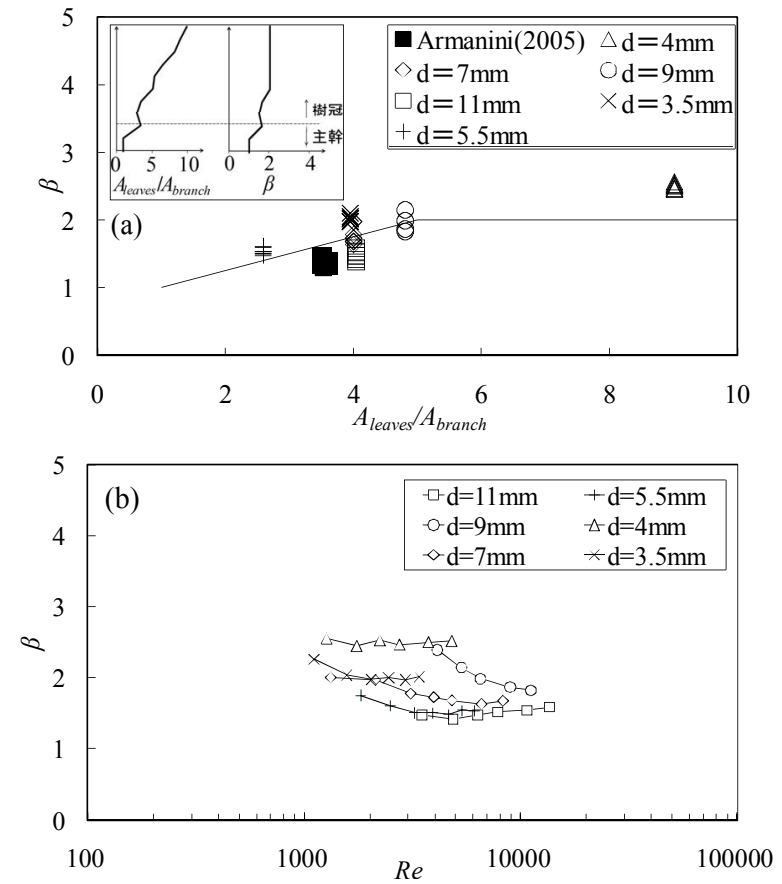

図-7葉層の付加抵抗 $\beta$, (a) $\beta$ と解析による樹木 $A_{\text {laeves }} / A_{\text {branch }}$ の関係, (b) $\beta$ 之Reの関係

ジュ，ヤナギどちらの場合も主幹全面に同様のTrunk-R のような粗度を有する（図-3）。そのため，実スケール の樹木に適用寸る場合は，部分粗度を有する Trunk-Wで はなく全面粗度を有するTrunk-Rのケースが適切である.

\section{(3) 実験3}

図-7に $A_{\text {leaves }} / A_{\text {branch }}$ （=枝葉の投影面積/枝の投影面 積） と葉による付加抵抗 $\beta$ の関係， $\beta$ とReの関係を示す. 投影面積は無風時のものを使用した，本実験結果は，水 流で行われた既往研究8) と同様の值を示寸。また， $A_{\text {leaves }}$ $/ A_{\text {branch }}$ が増加すると， $A_{\text {leaves }} / A_{\text {branch }}$ が4程度までは $\beta$ が大 きくなる，これより， は水流でも適用可能であり，ま た葉の量に応じて $\beta$ を決定する必要があることがわかる。 また， $\beta$ の值は高Reになるにつれ低下寸るが，高Reにな り変形が大きくなるとほぼ一定の值を示寸ことがわかる. 後述する検証計算では，ヤナギの枝葉分布と本実験の結 果をもとに， $\beta$ は葉の割合に応じて与えることとした.

\section{(4) 実験4}

図-8に，上流側に模型がある場合での抗力減少の効 果 (遮蔽効果) 影響を示す. 縦軸に樹冠域の遮蔽効果 $S_{c}$ $=\left(C_{D \text {-rear }} / C_{D}\right)$, 横軸にRe $e_{b}$ (代表長さは枝の直径) を示し ている．葉がある場合の遮蔽効果は低R $e_{b}$ 領域では大き いが，Re $e_{b}$ が大きくなり葉が変形してしまうと一定にな る。葉がない場合はRe $e_{b}$ にらず一定の值を示す，実験 した枝葉間距離では，高 $R e_{b}$ 領域における $S_{c}$ は葉の有無 によらず約 0.95 示すことがわかった．なお，水流にお いても葉の収縮による抗力係数の減少は報告されており， 水流にも適用可能と考えられる.

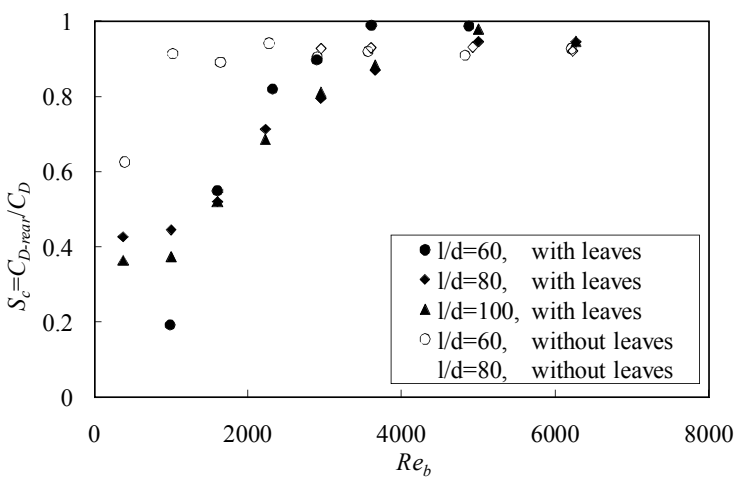

図-8 枝葉の遮蔽係数 $S_{c}$ の $R_{b}$ による変化. $l / d$ は, $l$ : 枝と枝の距 離, $d:$ 枝の直径
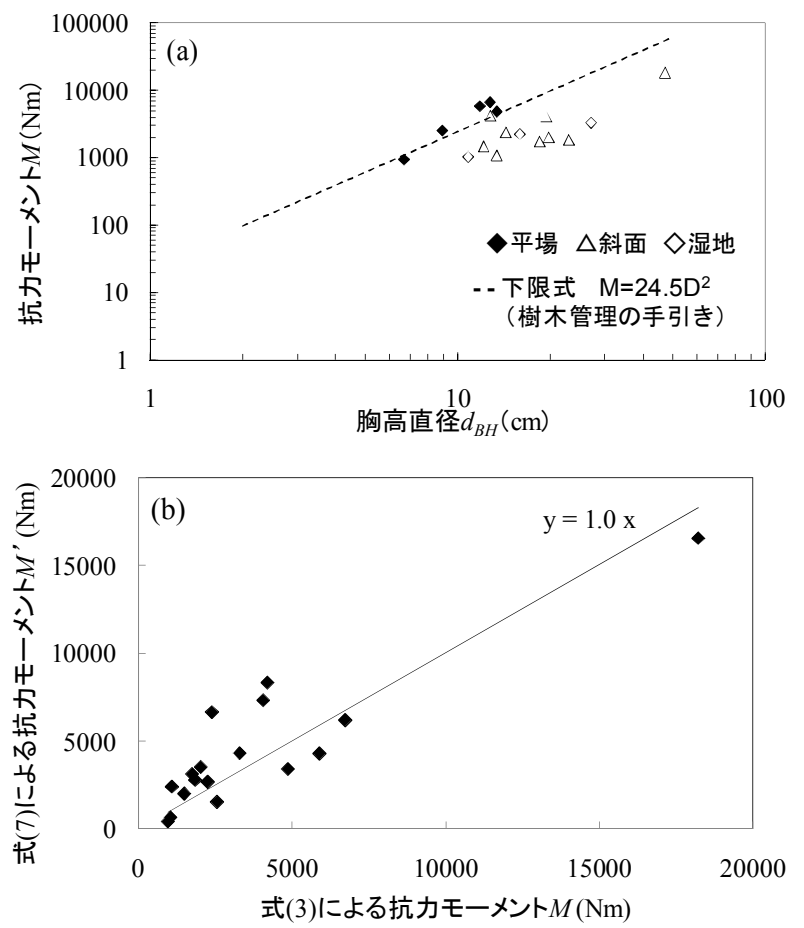

図-9 倒伏樹木の抗力モーメント，(a)計算值 $M$ と胸高直径 $d_{B H}$ の関係，(b)式(3), 式(7)で計算した $M, M^{\prime}$ の比較

\section{4. 樹木規模での検証と考察}

倒伏した樹木について, 式(3)により算出した抗力 モーメント計算值 $M$ と胸高直径 $d_{B H}$ の関係を, 図-9 (a) に

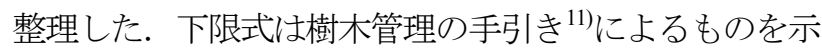
す。台風18号強風で，平地で倒れたものは概ね下限值を 超えたところで発生している. また，斜面（限界は半分 程度と推定される）や根張りの悪いもの（根の深さが通 常の半分以下）の風倒木の推定值が下限式を下回った位 置にあるのは，その強度から考えておおむね妥当である と考えられる。 また， $\beta$ に関して既往研究の值 $1.4^{7}$ ， $1.25^{8)}$ を用い倒伏樹木の抗力モーメントを求めると, 式 (3)より算出した抗力モーメントより, それぞれ $23 \%$, 31\%程度低く見積もってしまう。よって，下限式を満た さない樹木があることとなる．なお, 遮蔽係数 $S_{t}, S_{c}$ を考 
慮すると，抗力モーメントを $3 \%$ 程度低く見積もる。ま た，式(3) と式(7)より算出した抗力モーメントの比較を 図-9(b)に示寸，同図における式(7)の值は，近似式の係 数が1になるよう, 樹冠域に対寸る抗力係数 $C_{D}$ 'を設定し た結果， $C_{D}{ }^{\prime}=0.18$ となることがわかった. 樹木管理の 手引きにおける $C_{D}$ にあたるものは0.6 0.8で与えられて いるが, その他の既往研究 ${ }^{13)}{ }^{14)} て ゙ は C_{D}{ }^{\prime}=0.15 \sim 0.35$ の範 囲である.これは投影面積の定義が樹冠域内の空隙を含 むか含まないかの違いによるものと考えられる. 式(7) では樹冠幅と樹冠高さから投影面積を求めているため, 樹冠域内の空隙を含んで求めている. またヤナギの枝面 積の樹冠総面積に占める割合が高くないことから，既往 研究 ${ }^{13)},{ }^{14)}$ の下限に近い $C_{D}{ }^{\prime}=0.18$ は確からしい值である といえる. よって, 樹木の鉛直構造を考慮し, 葉の量に 応じた $\beta$ 用いることで実樹木の抗力係数が算定可能で あるといえる．本計算方式は，洪水の場合では洪水位に 応じた抗力係数を与えられるというメリットがある.

\section{6. おわりに}

本研究によって得られた結論を以下に示す.

1) 実樹木の幹では, 表面粗度の影響により, Trunk-R, Trunk-W いずれの抗力係数も Re によらず滑面円柱 である Cylinder-S の抗力係数よりも小さくなった.

2）幹の遮蔽効果は $l / d$ により変化する．また，表面粗 度の違いによりまったく違った傾向を示寸．幹が太 く樹皮の溝が発達した場合は Trunk-R の值を用いる ことが望ましい.

3) $A_{\text {leaves }} / A_{\text {branch }}$ が大きくなると葉による付加抵抗が大 きくなり約2になるが， $A_{\text {leaves }} / A_{\text {branch }}$ が5以上ではそ の傾きは小さくなる.

4) 低 $R e_{b}$ 領域では葉の影響によって樹冠域の遮蔽効果は 大きいが，高R $e_{b}$ 領域では葉の有無によらず樹冠域の 遮蔽係数 $S_{c}$ は約 0.95 を示寸.

5）樹木の鉛直構造を考慮して算出した抗力モーメント は樹木の倒伏限界值をおおむ袊足していた。また， 樹冠総面積に対する抗力係数 $C_{D}$ 'を算出したところ, $C_{D}{ }^{\prime}$ 'は既往研究による值と同等となったことから, 鉛 直分布計算法の正当性と有効性が検証された。

謝辞 : 本研究の一部に, 独立行政法人日本学術振興会の 「アジア・アフリカ学術基盤形成事業」（コーディネー ター・田中規夫）の助成を使用した。また，八木澤順治 助教, Phyo Min Htet氏，森永泰司氏に実験，現地調查を 手伝っていただいた，記して謝意を表します。

\section{参考文献}

1)重枝未玲, 朝位孝二, 坂本洋, 長太茂樹, 秋山壽一郎, 樋口 直樹, 重岡広美, 徳永智宏: 樹木群を考慮した平面 2 次元数
值モデルによる乙津川の洪水流解析, 水工学論文集, 第51巻, pp.171-176, 2006.

2)重枝未玲, 朝位孝二, 坂本洋, 西尾崇, 秋山壽一郎, 重岡広 美，樋口直樹，徳永智宏 : 大野川と乙津川の河道内樹木群が 有する治水機能の検討, 水工学論文集, 第51巻, pp.595-600, 2007.

3)Wieselsberger, C.: Neuere feststellungen uber die gesetze des flussigkeits-und luftwiderstands, Phys. Z., Vol.22, pp.321-328, 1921.

4)Achenbach, E.: Influence of surface roughness on the cross-flow around a circular cylinder, J. Fluid Mech., Vol.46, pp.321-335, 1971.

5)Takenaka, H., Tanaka, N., Phyo, M.H. and Yagisawa, J.: Wind Tunnel Experiments on Direct Measurement of Drag Force of Real Tree Trunks and Branches and Their Sheltering Effects at High Reynolds Numbers, International Symposium on Ecohydraulics, 8th, pp.1520-1525, 2010.

6)Tanaka, N., Yagisawa, J.: Flow Structures and Sedimentation Characteristics around Clump-Type Vegetation, J. Hydroenvironment Research, Vol.4, pp.15-25, 2010.

7)福岡捷二, 藤田光一, 平林桂, 板野章 : 樹木群の流水抵抗に ついて, 水理工学論文集, 第31巻, pp.335-340, 1987.

8)Armanini, A., Righetti, M. and Grisenti, P.: Direct measurement of vegetation resistance in prototype scale, J. Hydraulic Research, Vol.43, No.5, pp.481-487, 2005.

9)田中規夫，佐々木寧 : 2006年ジャワ津波災害において海岸林 が果たした役割とその破断・なぎ倒し限界, 水工学論文集, 第51巻, pp.1445-1450, 2007.

10)Bokain, A., Geoola, F.: Wake-induced galloping of two interfering circular cylinder, J. Fluid Mech., Vol. 146, pp.383-415, 1984.

11)(財)リバーフロント整備センター編 : 河川における樹木管理 の手引き, 山海堂, pp.147-171, 1994.

12)Uematsu, Y., Yasuda, M.: Effect of aspect ratio and surface roughness on the time-averaged aerodynamic forces on cantilevered circular cylinders at high Reynolds number, J. Wind Engineering and Industrial Aerodynamics, Vol.54, pp.301-312, 1995.

13)Su, H.-B., Schmid, H.P., Vogel, C.S., and Curtis, P.S.: Effects of canopy morphology and thermal stability on flow and turbulence statistics observed inside a mixed hardwood forest, Agricultural and Forest Meteorology, Vol.148, pp.862-882, 2008.

14)Endalew, A.M., Hertog, M., Gebrehiwot, M.G., Baelmans, M., Ramon, H., Nicolaï, B.M. and Verboven, P.: Modelling airflow within model plant canopies using an integrated approach, Computers and Electronics in Agriculture, Vol.66, pp.9-24, 2009.

15)Takemura, T., Tanaka, N., Flow structures and drag characteristics of a colony-type emergent roughness model mounted on a flat plate in uniform flow, Fluid Dynamics Research, Vol.39, pp.694-710, 2007.

16)田中規夫，八木澤順治，Methsiri Samarakoon，佐々木寧，利 根川誠 : 地盤強度と根の形状特性が樹木転倒限界に与える 影響について，河川技術論文集，第16巻，pp.225-230, 2010.

(2010. 9. 30受付) 